\title{
Learning Local Content of Cultural Arts Based on Local Genius of Sasak Culture in PGSD Students
}

\author{
Muhammad Tahir* \\ Primary Teacher Education Study \\ Program \\ University of Mataram \\ Mataram, Indonesia \\ mtahir_fkip@unram.ac.id
}

\author{
Muhammad Sobri \\ Primary Teacher Education Study \\ Program \\ University of Mataram \\ Mataram, Indonesia \\ muhammadsobri@unram.ac.id
}

\author{
Setiani Novitasari \\ Primary Teacher Education Study \\ Program \\ University of Mataram \\ Mataram, Indonesia \\ setianinovitasari@unram.ac.id
}

\author{
N Nursaptini \\ Primary Teacher Education Study Program \\ University of Mataram \\ Mataram, Indonesia \\ nursaptini@unram.ac.id
}

\author{
Ashar Pajarungi Anar \\ Primary Teacher Education Study Program \\ University of Mataram \\ Mataram, Indonesia \\ asharpajarungianar@unram.ac.id
}

\begin{abstract}
This study aims to determine the form of reinforcement in learning local content of arts and culture based on the local genius of Sasak culture. The approach used in this research is descriptive qualitative. This research was conducted on PGSD students. Determination of research subjects using purposive sampling. The subjects of the study were 37 lecturers and students of grade $7 \mathrm{~B}$ regular morning. Data collection was carried out through observation, interviews, and documentation. Data validity was done by expanding observations, increasing persistence, triangulation, and member checks. Data analysis was carried out following Milles and Huberman's model, namely data reduction, data presentation, and verification of conclusions. The result of this research is that the strengthening of local content learning of local cultural arts based on Sasak cultural genius is carried out through learning that is carried out by always linking local genius values in every material, not only in the form of concepts. The learning material presented relates to the state of an area and explains that a tradition does not exist in a place. There are some differences in the implementation stage depending on each region. This difference does not eliminate the original meaning contained in the existing traditions. As a form of strengthening and arousing curiosity and critical thinking, each learning session includes a video related to material about Sasak culture. The video contains about Sasak culture and the opinions of cultural observers as a reference for students to better understand the Sasak culture.
\end{abstract}

Keywords—learning, local genius, sasak culture.

\section{INTRODUCTION}

In essence, social life is always inherited, interpreted, implemented in line with the values contained in culture. The manifestation and legitimacy of society towards culture is a form of the implementation of cultural values itself. Preserving the values contained in the local culture can create the character of a nation [1] The private and public character that builds the character of citizens is a form of cultural existence as well as the diversity of noble cultural values that the Indonesian nation itself has [2].

Local content is one of the courses that must be followed by every PGSD student of Mataram University. Local content is a course that serves to provide education on how to get to know the local culture in each area and how to get efforts in its preservation. Students must have sufficient knowledge to be able to go into the field later so that they can educate their students later about the local content itself. So that through local content it is expected to strengthen the existing curriculum related to character strengthening [3].

The reality that occurs in the 7th-semester students of PGSD at the University of Mataram is still found that many students do not understand and master the local content that is in their respective places. Of course, this is a concern that can threaten the preservation of culture itself. Therefore, it takes an interesting and applicable learning process to support student understanding through lectures[4].

Learning local content based on the local genius of Sasak culture as a solution to improve students' understanding of cultural literacy. Local wisdom that is practiced as Local Genius is the values and norms that become the reference for a community group in acting that believes in the existence of existing norms and values. So that for the benefit of the community, it is necessary to empower the potential values that contain goodness wisely and wisely that have been passed down by the ancestors [5].

The implementation of meaningful learning for students is carried out by inserting the values of local wisdom as a means of cultural literacy [6]. Cultural literacy is knowledge and skills in understanding and behaving towards Indonesian culture as a national identity [7]. Local cultural wisdom is the concept, ideas, and ideas of local culture that are wise and used as a way of life for the local community [8].

Local cultural literacy that requires this value can be used as a means of social learning for the younger generation. The younger generation, including students, are expected to behave following the values and norms that exist in their culture [9]. Literacy can be a funnel to increase students' intellectual, emotional, and spiritual capacity [10].

An appropriate and tested cultural development strategy is considered very important [9]. The method used is in the form of refreshing knowledge and training through teaching local cultural wisdom in the form of objects of art, stories, food, and others to train students to better understand cultural literacy [11]. Thus cultural literacy can be conveyed through experiences of sharing culture, not just literature [12]. 


\section{METHODS}

The research method used in this research is qualitative research with a descriptive approach. The research location was carried out in the regular morning PGSD Semester VII Study Program. The unit of analysis that is the target of this research is the Student of Semester VII B Regular Morning, which amounts to 37, and lecturers who teach the Local Content of the Regional Arts and Culture courses. Determination of research subjects using purposive sampling, namely selecting samples based on subjective judgments about the unit of analysis that is most representative of the problem being studied. Data were obtained through primary and secondary data sources. The data collection technique is done through observation, interview, and documentation. Furthermore, for data validity, it was carried out through extension of observations, increasing persistence, triangulation, and holding member checks, while for data analysis using data analysis steps Milles and Huberman's models consisting of data reduction, data presentation, and verification of conclusions.

\section{RESULTS AND DISCUSSION}

Based on the results of triangulation of data through interviews, observation, and documentation study, it was found that: Learning local content of arts and culture based on local genius is a form of transforming local wisdom values in every learning process that is carried out. The existence of initiatives to strengthen local genius in learning is one of the efforts to reduce global influences that damage the local wisdom values of an area in line with the current modernization.

In the learning process based on local genius, lecturers not only instill an understanding of the concepts but also explore the meaning of concepts or terms in local genius-based local content courses. This can be seen in the results of observations during the lecture, namely when learning begins by explaining the material, the lecturer explains the concept of the material associated with the meaning of local wisdom values, one example is the tradition of marriage in the Sasak tribe, related to Ajikrame. The lecturer explained that the payment of Ajikrame is mandatory and is an effort so that the marriage contract can be carried out immediately. Whereas Pisuke is a request for other payments, such as an amount of money or valuables, intended for healers or pleasers so that the woman's family becomes like giving up or giving up. Pisuke is used for welcoming at Nyongkolan events and for holding thanksgiving events or receptions at women's homes. Furthermore, the lecturer also explained the meaning of Nyongkolan to reveal the meaning of disseminating information that the nagging partner is officially married to the community.

This situation is following the results of research [13] that students are given examples taken from everyday life. So that students get involved directly to better understand the meaning and indirectly preserve traditional cultural values. Furthermore, the results of research [14] explain the values contained in society as guidelines for behavior and as moral guidance.

Learning local content is also carried out based on the value of local wisdom in Sasak literature as shown in Table I.
TABLE I. THE VALUES OF LOCAL WISDOM IN SASAK LITERATURE

\begin{tabular}{|l|l|}
\hline \multicolumn{1}{|c|}{ Local genius } & \multicolumn{1}{c|}{ Implementation in learning } \\
\hline $\begin{array}{l}\text { Dendeq ipuh pantok Gong (do } \\
\text { not hesitate to hit Gong) }\end{array}$ & $\begin{array}{l}\text { Not ashamed to ask if there is a } \\
\text { material that is not understood }\end{array}$ \\
\hline $\begin{array}{l}\text { Lolon kayuq pasti tebabar isiq } \\
\text { angin (every wooden tree must } \\
\text { be hit by the wind) }\end{array}$ & $\begin{array}{l}\text { Identify difficulties experienced by } \\
\text { students in learning activities so that } \\
\text { they can be resolved as quickly as } \\
\text { possible }\end{array}$ \\
\hline $\begin{array}{l}\text { Lebur anyong saling sedok (it's } \\
\text { hard to be happy staying } \\
\text { happy) }\end{array}$ & $\begin{array}{l}\text { Directing and motivating students to } \\
\text { continue to support each other } \\
\text { during learning activities carried out. }\end{array}$ \\
\hline $\begin{array}{l}\text { Aiq meneng, tunjung tilah, } \\
\text { empak bau (the water remains } \\
\text { clear, remains intact, even fish } \\
\text { can). }\end{array}$ & $\begin{array}{l}\text { Upholding the value of deliberation } \\
\text { in learning activities so that it runs } \\
\text { orderly and effectively }\end{array}$ \\
\hline $\begin{array}{l}\text { Ndak bait doen dengan laun } \\
\text { cekok (do not take other } \\
\text { people's goods later his hands } \\
\text { are bent) }\end{array}$ & $\begin{array}{l}\text { Not cheating when given exams or } \\
\text { questions to answer. }\end{array}$ \\
\hline
\end{tabular}

Based on the table above, provides an understanding that in the local content learning process there are several values of local genius that are implemented for the smoothness and effectiveness of learning. The values of local wisdom contained in Sasak literature as seen in Table I above are often expressed in learning to increase students' understanding of cultural literacy.

Strengthening local culture by linking concepts with experiences gained in everyday life is more effective and easier to implement. The learning process by utilizing culture, language, and daily life can indirectly preserve local culture [15]. One example is the results of Wayan Ardhi's research that the tradition of Topat warfare is carried out by the Sasak tribe regardless of religion. Three aspects are used as cultural guidelines, namely balance, harmony, and life harmony. [16].

Furthermore, in Mulok (Muatan Lokal) or local content learning, the lecturer delivers material by displaying learning videos that come from cultural observers, this will certainly provide a comprehensive understanding to students. This is as the results of interviews with informants that: "The use of learning media used during lectures in Mulok is very helpful in understanding the material. Besides, it is motivated to find out what is the local culture, what is the meaning of culture and what is the meaning contained in our local culture."

Based on the results of observations, interviews, and documentation studies, it can be understood that the form of strengthening local content learning based on local genius is carried out through providing an understanding of the meaning of a culture, not just a concept, besides implementing the value of local wisdom in learning activities, then providing a comprehensive understanding by presenting learning videos that come from cultural observers.

Learning local content based on local genius is an asset in a more meaningful teaching and learning process. The application of local genius in learning is also useful for instilling character education values in students such as independence, help, deliberation, honesty, and discipline [17]. Each region has a local genius value [18].

Local genius in the learning process can increase critical thinking power [19] Local genius-based learning is also one of the strategic efforts of the nation's mental revolution. [20]. The role of local genius in building mental revolution is an 
answer to the phenomenon of social change that occurs in society, especially changes in local cultural values due to the clash of the current globalization

\section{CONCLUSION}

Based on the results of this study, several things can be concluded as follows: (1) Students are trained to think critically about the current state of the Sasak culture. (2) Students can understand the Sasak culture, not only its implementation but also the meaning contained in the Sasak culture itself. (3) Strengthening the Sasak culture is carried out by reinforcing the concept (material) and accompanied by instructional videos along with the opinions of cultural observers. (4) Teaching materials based on the local genius that is following the surrounding conditions give rise to learning interest for students, especially in understanding Sasak culture as a regional cultural identity. (5) Learning based on local genius is a way to preserve the cultural values of Sasak for students so that they can be studied and applied in life so that they are not lost to the times.

\section{REFERENCES}

[1] I. K. N. Ardiawan, "Ethnopedagogy And Local Genius: An Ethnographic Study," SHS Web Conf., vol. 42, p. 00065, 2018.

[2] R. Yunus, Nilai-nilai kearifan lokal (Local Genius) Sebagai Penguat Karakter Bangsa Studi Empiris Tentang Huyula. Yogyakarta: Deepublish, 2014.

[3] I. W. Rasna and D. K. Tantra, "Reconstruction of Local Wisdom for Character Education through the Indonesia Language Learning: An Ethno-pedagogical Methodology,” Theory Pract. Lang. Stud., vol. 7, no. 12 , p. 1229,2017

[4] G. A. S. P. Ribut, I. B. G. Y. Triguna, and I. W. Suija, "Didactic Strategy of Wetu Telu Cultural Heritage on Sasak Tribe (Lembuak and Nyurlembang Village in Narmada ),” Int. J. Linguist. Lit. Cult., vol. 5, no. 3, pp. 9-17, 2019.

[5] I. Ruslan, "Dimensi Kearifan Lokal Masyarakat Lampung Sebagai Media Resolusi Konflik," Kalam, vol. 12, no. 1. p. 105, 2018.

[6] D. Desyandri, "Nilai-Nilai Kearifan Lokal untuk Menumbuhkembangkan Literasi Budaya di Sekolah Dasar," Sekol. Dasar Kaji. Teor. dan Prakt. Pendidik., vol. 27, no. 1, pp. 1-9, 2018.
[7] T. G. Kemendikbud, Panduan Gerakan Literasi Nasional. Jakarta: Kementerian Pendidikan dan Kebudayaan Pusat Data dan Statistik Pendidikan dan Kebudayaan, 2017.

[8] I. Oktavianti., E. Zuliana., and Y. Ratnasari., "Menggagas Kajian Kearifan Budaya Lokal di Sekolah Dasar Melalui Gerakan Literasi Sekolah,” Pros. Semin. Nas., pp. 35-42, 2017.

[9] E. Saepudin, N. A. Damayani, and A. Rusmana, "Model literasi budaya masyarakat Tatar Karang di Kecamatan Cipatujah Kabupaten Tasikmalaya,” Berk. Ilmu Perpust. dan Inf., vol. 14, no. 1, p. 1, 2018.

[10] H. Ahmadi, Farid Ibda, Media Literasi Sekolah (Teori dan Praktik). Semarang: CV Pilar Nusantara, 2018.

[11] S. Susanti and R. S. M. Permana, "Pembelajaran Literasi Budaya Sunda pada Peserta Didik Sekolah Dasar Utami Kab. Garut, Jawa Barat," J. Apl. Ipteks untuk Masy., vol. 5, no. 1, pp. 34-37, 2016.

[12] G. Aprinta, "Fungsi Media Online Sebagai Media Literasi Budaya Bagi Generasi Muda," J. Messenger, vol. 5, no. 1, p. 16, 2013.

[13] K. Sukenti, L. Hakim, Y. Purwanto, and P. J. Matthews, "Ethnobotanical study on local cuisine of the Sasak tribe in Lombok Island, Indonesia,” J. Ethn. Foods, vol. 3, pp. 189-200, 2016.

[14] L. N. Yaqin and T. Shanmuganathan, "SOCIAL SCIENCES \& HUMANITIES Politeness Strategies of The Pembayun ( $\mathrm{s}$ ) in The Bride- Kidnapping Practices of Sasak Culture," Soc. Sci. Humanit., vol. 28 , no. 1, pp. 89-102, 2020.

[15] Hilmiati, H. Suwignyo, D. Saryono, and Roekhan, "Examining the implementation of Culturally Responsive Teaching Materials (CRTM) of Sasak culture literature using Culturally Responsive Teaching (CRT),” Int. J. Humanit. Innov., vol. 2, no. 1, pp. 13-20, 2019.

[16] I. W. A. Wirawan, "Maintaining Social Relationship of Balinese and Sasak Ethnic Community,” Int. J. Soc. Sci. Humanit., vol. 2, no. 1, pp. $92-104,2018$

[17] Z. K. Prasetyo, "Pembelajaran Sains berbasis Kearifan Lokal," Pros. Semin. Nas. Fis. Dan Pendidik. Fis., vol. 2, no. September, pp. 1-14, 2013

[18] M. Munir and M. G. R. Pandin, "The Local Genius Values of Minangkabau Society," in Proceedings of the International Conference of Communication Science Research (ICCSR 2018), 2018, pp. 302306.

[19] D. Gularso, B. D. Lukitoaji, and F. Noormiyanto, "Efektifitas Penggunaan Model Pembelajaran Pendidikan Kebudayaan Daerah Berbasis Local Genius, Local Wisdom, Dan Riset Ditinjau Dari Keterampilan Berpikir Kritis Calon Guru Sekolah Dasar,” J. Bid. Pendidik. Dasar, vol. 1, no. 1, pp. 1-10, 2017.

[20] S. Samsudin, "Local Genius Dalam Revolusi Mental Bangsa," vol. 9, no. 1, pp. 35-41, 2016. 